\title{
Private donors breathe new life into US stem cell research
}

Two days after The Wall Street Journal published his 1 March column supporting stem cell research, Michigan State University researcher Jose Cibelli was still screening calls from both angry opponents and ardent supporters.

Despite being besieged, however, Cibelli sounded distinctly upbeat. Harvard University had just confirmed plans for a large embryonic stem cell research center, and New Jersey and California had already announced plans to support stem cell research.

"I think it's wonderful," said Cibelli, whose collaboration on stem cell research with South Korean researchers recently made a big splash. "What we need is more talented people to get into this field without fear-and the only way you are going to get that is to work under an umbrella like Harvard, or with a state protecting you."

Faced with funding restrictions imposed three years ago by US President Bush, many scientists passed on stem cell work. But a handful of states and private philanthropies are taking matters into their own hands.

\section{Embryo research stirs up Spanish spat}

Control over Spain's first public stem cell bank pitted the now-ousted conservative central government against authorities in the southern region of Andalusia, which launched the bank in January. With the election on 14 March of the Socialist Party, however, the tussle could well take a new turn.

The battle began last October when the Andalusian government approved legislation permitting embryo research. Just one week later, the Spanish Parliament approved a new law on assisted reproduction that oversees the creation of a national center to store and manage human embryonic stem cell lines derived from spare embryos.

The Spanish government in November filed a lawsuit contending that the Andalusian center is unconstitutional. Three weeks later, Andalusia responded with its own lawsuit against the Spanish government, also in the Constitutional Court, saying the new national law represents a "flagrant invasion of regional competencies."

The \$6 million Andalusian stem cell bank is located in a research center in Granada, and is expected to be fully operational by 2005. In the meantime, says Andalusian health minister Francisco Vallejo, cell lines

Pending state-level bills on stem cell research (as of $\mathbf{3}$ March)

Permit stem cell research, prohibit reproductive cloning

Permit stem cell research, do not address cloning

Restrictions on stem cell research

Multiple bills in process
California residents have until 16 April to collect enough signatures to put a $\$ 3$ billion funding plan on the state ballot. New Jersey Governor James McGreevey's 2005 budget proposal includes $\$ 6.5$ million in seed money for a new research center. Private donors are also funding efforts at Stanford University and the University of California in San Francisco.

As some states consider endorsing stem cell research, however, others are moving toward more restrictions. Most of the bills pending in state legislatures would put limits on

will be imported from stem cell banks at the Stockholm-based Karolinska Institute and in the UK. Because the new national law prohibits the purchase of foreign lines, Vallejo says, researchers have reached agreements with the institutes allowing them access to the lines for just shipping costs.

The outcome of the lawsuits could have a significant impact on the fate of the Andalusian center. The national law is more restrictive and only permits research on surplus embryos that will have been stored for more than five years by the time the law goes into effect. It also limits the number of embryos and eggs to be fertilized. "I cannot accept that [stem cell] research in Andalusia has different rules," central health minister Ana Pastor said in a statement.

Josep Egozcue, an embryologist at the Autonomous University of Barcelona, says regional communities have "full competencies in research," and the national law may be unconstitutional. Egozcue was a member of the Spanish health ministry's commission on assisted reproduction, but resigned his post because of disagreements with Pastor. The Constitutional Court is expected to issue a shared verdict on both lawsuits by this summer.

Xavier Bosch, Barcelona

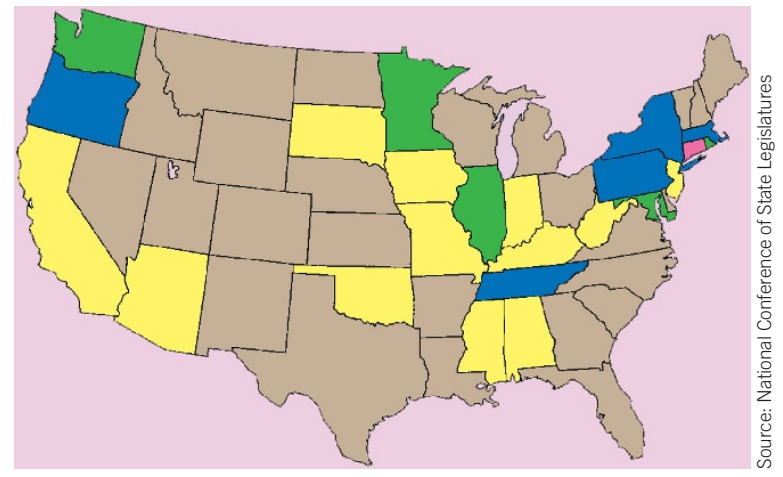

therapeutic cloning, research on human embryonic stem cells, or both, says Alissa Johnson of the National Conference of State Legislatures in Washington DC. As of 3 March, 32 bills are pending in 18 states.

"The US as a whole may serve as a microcosm for what we are seeing internationally in the competition to lead the way into stem cell research," Johnson says. "Some states-like some countries-will not enter the arena for either ethical, legal or financial reasons, while others will create incentives and look for strategies to draw top researchers to their state."

Even when new stem cell lines become available, researchers have to muddle through the daunting logistics of working with different funding sources for different cell lines. For instance, when Harvard researcher Douglas Melton announced that he had created 17 new cell lines, Harvard carefully noted that the work was done in a new, completely separate, basement laboratory.

The US National Institutes of Health has never required separate labs-just separate funding streams, says James Battey, chair of the NIH Stem Cell Task Force. But some scientists say the agency only recently clarified those rules.

Just days before the Harvard announcement, the Bush administration dismissed two supporters of stem cell research from the president's bioethics panel. One of them, cell biologist Elizabeth Blackburn, later revealed that references to disappointing research on adult stem cells had been cut from the panel's reports.

The US's conservative stance on stem cell research could change come November if Democratic candidate John Kerry replaces President Bush. Until then, says Johnson, state-level legislation is likely to have the biggest impact. "Take a look at the state and see who the relevant actors are," she says. "In the end, things will shake out based on whoever has the greatest influence in that state."

Tinker Ready, Boston 